\title{
Subendothelial matrix as the playground for "diabetic milieu" factors in development of angiopathy
}

\author{
K. A. Nizheradze ${ }^{1}$, A. I. Khoruzhenko ${ }^{2}$ \\ ${ }^{1}$ Bogomolets National Medical University \\ 13, Shevchenko Blvd., Kyiv, Ukraine, 01601 \\ ${ }^{2}$ Institute of Molecular Biology and Genetics, NAS of Ukraine \\ 150, Akademika Zabolotnoho Str., Kyiv, Ukraine, 03143 \\ konsnizher@gmail.com
}

Despite a few decades of intensive researches, the coherent view on the effector mechanisms causing development of diabetic angiopathy remains in demand. At the level of the whole organism, stable or intermittent hyperglycemia along with the altered levels of insulin, glycosylated proteins and lipoproteins, accompanied by modulation of intracellular metabolic pathways are considered as the main causative factors of diabetic micro- and macroangiopathy. At the tissue level, the general manifestation of vascular damage in diabetes appears as the basal membrane thickening. Here, based on the available literature and own experimental data, the changes in local microenvironment are considered as an important intermediate step in the realization of the effects of "diabetic milieu" factors on vessel wall cells. Special attention is paid to the carbohydrate determinants and deposition of von Willebrand factor in subendothelial matrix produced by endothelial cells in vitro.

Ke y word s: diabetic angiopathy, hyperglycemia, basal membrane, von Willebrand factor.

\section{Introduction}

The development of micro- and macroangiopathy at diabetes is the most common and formidable complication that accompanies this disease $[1,2]$. Despite several decades of research work, the mechanisms underlying the development of vascular pathology at diabetes remain incomprehensible, and even the question about the common basis of the damage of large and small vessels is disputable [3]. The declared primary role of hyperglycemia in the impairment of endothelial function is based on the indisputable fact that diabetes mellitus (both types I and II) is always manifested by the fluctuations of glucose level, and that its stable compensation is the way to improve the patient's state. This mainly concerns microangiopathy, which is related to the violation of capillary function, but in the case of macroan-

(C) 2020 K. A. Nizheradze et al.; Published by the Institute of Molecular Biology and Genetics, NAS of Ukraine on behalf of Biopolymers and Cell. This is an Open Access article distributed under the terms of the Creative Commons Attribution License (http://creativecommons.org/licenses/by/4.0/), which permits unrestricted reuse, distribution, and reproduction in any medium, provided the original work is properly cited 
giopathy, which is represented by dysfunction of large vessels, such relationship does not seem so well-grounded. It should be emphasized that macroangiopathy continues to develop even at relatively stable maintenance of normoglycemia [4]. It brings us back to the issue about the causes of observed vascular pathology, which is so closely related to the course of diabetes. Even if to assume the dominant role of hyper/hypoglycemia in this process, we have to consider also other probable etiological factors, the role of which may be hidden or underestimated.

Diabetic angiopathy affects almost all parts of the vascular system: from large arteries to capillaries [5]. A hallmark of these disorders is the thickening of the basal membrane that separates the endothelium from the underlying cells. Apparently, without understanding the mechanisms of this phenomenon, associated with extracellular matrix remodeling, it will be difficult to advance in elucidation of the onset and course of the diabetic angiopathy. The situation is further complicated by the fact that not only endothelial cells, but also adjacent pericytes/smooth muscle cells are involved in production of basal membrane (the latter two cell types represent small and large vessels, respectively) [6]. It could be pointed out that the alteration of physicochemical and biological properties of the vascular basement membranes, caused by diabetes, still has not been sufficiently studied to date. However, it seems unlikely that observed changes in the level of glucose, intermittent concentration of insulin, or plasma lipoprotein spectrum, as well as the appearance of glycosylated plasma proteins, directly lead to modification of subendothelial matrix. The main argument here again is provided by the fact that even with sustained stable normoglycemia maintained by adequate fractional insulin administration, the development of vascular pathology remains possible. An additional argument is as follows: ex vivo incubation of cultured human endothelial cells under the conditions of "severe" hyperglycemia (28 mM glucose), with/without the addition of "exogenous" insulin, did not cause significant changes in morphology or behavior of individual endothelial cells, as well as of the cell clusters [7]. On the other hand, it could not be ruled out that the processes leading to the development of vascular pathology, take place before the complete manifestation of diabetes [8]. If to extrapolate this to experimental diabetology, the timing of experiments becomes a critical parameter. Therefore, it is reasonable to add into consideration the factors, which could continuously alter the local microenvironment of vascular cells and change the intercellular interactions in some parts of vascular system. This change can be realized through the activation of intracellular signaling pathways [9] and finally leads to essential alteration of the basal membrane remodeling.

If to assume that the development of diabetic angiopathy could be closely connected with modification of microenvironment of vascular cells, the role of the factors of "diabetic milieu", which affect all tissues and organs, should be considered through the prism of local regulatory mechanisms existing at the tissue levels. In this context, the subendothelial matrix represents the most probable playground where these local regulatory mechanisms are realized. The common feature of vascular (and non-vascular) basement mem- 
brane thickening at diabetes is an increased deposition of collagen IV, laminin and fibronectin. This is accompanied by a decreased level of heparan sulfate proteoglycan and a change in the cell-matrix interaction mediated by integrins $[10,11]$. It was revealed earlier that the extracellular matrix serves as a selective barrier via binding and releasing biologically active molecules, thereby modulating the intracellular processes [12]. The degradation of extracellular matrix by matrix metalloproteinases could also be involved in the reorganization of vascular cell local environment. High glucose can upregulate the activity of matrix metalloproteinases and cause an imbalance between these proteinases and their tissue inhibitors [13]. Special attention should be given to carbohydrate determinants of basal membrane, which is rich in oligosaccharides attached to laminin and nidogen [6]. Also, it should be taken into account the assumed role of matrix glycosaminoglycans as "information network" mediating the effects of growth factors [14].

\section{Modeling of diabetic angiopathy in vitro}

When analyzing the available data on angiopathy from the point of view of the experiment's design, it is necessary to keep in mind that in some cases the absence of evident effects of hyperglycemia or insulin on vascular cells under experimental conditions may be due to inadequate period of exposure to the factors under study. Given that the effects of activators or inhibitors of the mTOR/S6K signaling pathway responsible for the insulin signal transduction through the phosphorylation of IRS-1 are frequently estimated in less than $1 \mathrm{~h}$ after incubation [15]. At the same time, to reach the effects of the "diabetic milieu" related to in vivo conditions, much longer experiments could be imagined - when the cells are cultured for several months, or even years. However, such experiments are difficult and in very deed - impossible. Therefore, we need to operate on the data obtained in shortterm experiments, when the cells are incubated only for a few (2-10) days. Besides, to characterize the state of cells we have to imply both the indices of cell viability and the evaluation of the functional activity of a studied type of cells.

Also, it can be added here that the cultivation of normal, untransformed endothelial cells has its own peculiarities, the main of which are the need to maintain direct intercellular contacts and a pronounced dependence of cell proliferation/migration on the presence of regulatory factors that have an external, nonendothelial origin. Failure to comply with such conditions leads to the lack of culture growth and to the activation of the processes associated with programmed cell death - apoptosis. Noteworthy, the endothelial cell cultures are unstable - their properties changed after 2-3 passages and the signs of degradation will appear. On the one hand, it makes the culture of endothelial cells quite difficult in methodological relation, but on the other hand it allows us to say that these cells during the early period of maintaining in vitro retain essential features inherent of the endothelium of large and small vessels in vivo [16].

The object widely used in studying vascular endothelium in vitro is the culture of endothelial cells obtained from large vessels of human or animal origin. Namely, human umbilical 
vein endothelial cells (HUVEC) were used most frequently $[17,18]$. The cultured endothelial cells from capillaries were used as well $[19,20]$, but their routine application is complicated by low output of cells after isolation from tissue and the necessity of additional purification of these endothelial cells from the adjacent cells with much higher proliferative index.

\section{Effect of "diabetic milieu" factors on subendothelial deposition of von Willebrand factor and carbohydrate determinants in vitro}

It is known that endothelial cells are characterized by constitutive secretion of prothrombogenic von Willebrand factor (vWF) [21]. Vascular endothelium is the key producer of $\mathrm{vWF}$, some amount of vWF is also present in platelets. The vWF produced is secreted into the blood, where it stabilizes factor VIII of the clotting system, or it is deposited in the subendothelial basement membrane, forming here the complexes with type IV collagen and fibronectin [22]. The deposited vWF, as a component of the extracellular matrix, mediates the platelet adhesion and thrombus formation. Because of that, the production and deposition of $\mathrm{VWF}$ could be considered as one of the significant indicators of the functional activity of the vascular endothelium. In this regard, it should be noted that diabetes, in general, is characterized by an increase in the coagulation properties of the blood, that is defined as a "hypercoagulable state" and one of the marker of endothelial dysfunction is an elevation (on average, twice) of the vWF in blood plasma of diabetic patients [ 23]. The vWf level increased with the severity of nephropathy and could be considered as a risk factor for macrovascular complications at diabetes [24]. Thus, to test a possible effect of the "diabetic milieu" factors (high glucose, insulin and glycosylated proteins) on production of $\mathrm{VWF}$, the abovementioned model of HUVEC monolayer culture can be used.

Previously, it was shown that elevation of glucose level increases the secretion of vWF by cultured endothelial cells into the incubation medium $[25,26]$. At the same time, similarly to in vivo conditions, these cells produce vWF into the underlying extracellular matrix (which is close to the basal membrane by composition) in significantly higher amount than it is secreted into the medium. Interestingly, using specific antibodies it is possible to visualize the distribution of vWF in produced subendothelial matrix. And, in accordance with the hypothesis formulated above, it seems reasonable to study the influence of "diabetic milieu" on the deposition of $\mathrm{vWF}$, and to evaluate the effects of local factors secreted by adjacent vessel wall cells smooth muscle cells, pericytes, and fibroblasts - using appropriate cultures of human (preferably) or animal cells. Such a mutual intercellular influence between neighboring cells was shown when studying atherosclerosis [27].

In previous research [7], it was studied the effect of increased glucose concentration in the culture medium and addition of insulin on the deposition of produced vWF into subendothelial matrix. In order to quantify the deposition of $\mathrm{vWF}$, the following approach had been used: after incubation, the cultured endothelial cells were detached from the growth surface; the subendothelial matrix, remaining 
on this surface, was used as a solid phase in ELISA with corresponding primary (anti-vWF) and secondary (enzyme-conjugated) antibodies [28].

So, when determining the deposition of $\mathrm{vWF}$ in produced subendothelial matrix, it was found that neither an increase in glucose concentration nor the addition of insulin affected the index under study. Likewise, there was no effect of the medium conditioned by skin fibroblasts on the quantity of vWF in the matrix. On the other hand, addition of the medium conditioned by smooth muscle cells to the endothelial cells led (in the presence of insulin) to a decrease in the accumulation of vWF. It is known that smooth muscle cells are able to produce vascular endothelial growth factor (VEGF), that affects the state of the endothelium and the properties of its extracellular matrix [29]. It is possible that the observed effect of smooth muscle cells on the deposition of $\mathrm{VWF}$ is associated with such a regulatory mechanism. This interaction between endothelial and smooth muscle cells is of special importance in the context of atherosclerosis, which is the main hallmark of macroangiopathy at diabetes $[27,30]$.

It is conceivable that diabetes induces not only quantitative, but also qualitative changes in subendothelial matrix. These changes may be directly related to abnormal angiogenesis at diabetes [31]. An important role of carbohydrate determinants and carbohydrate-recognition system in angiogenesis leads to an issue about their involvement in diabetic angiopathy $[32,33]$. Vascular endothelium is protected at the lumen side by the layer of glycocalyx [34]. Especially it concerns hyaluronic acid as the component of this layer. At diabetes the protec- tive properties of endothelial glycocalyx could be deteriorated [35]. One of the interesting and insufficiently studied questions is the influence of the "diabetic milieu" on the presence of carbohydrate determinants in produced subendothelial matrix. The advanced glycation end products are able to induce cross-link formation in structural components of basement membrane changing its stiffness [36]. The labeled plant lectins are applied to reveal the distribution of carbohydrate determinants in the matrix produced by cells in vitro [37]. Namely, the biotinylated lectins were used as probes in this research. After that, the presence of some saccharides in subendothelial matrix had been studied at elevated glucose level and addition of insulin to the incubation medium [7]. The binding of peanut lectin (specific to galactose residues) to the extracellular material produced by cultured endothelial cells was insignificant, and this is quite different from the extracellular matrix of cultured human skin fibroblasts [37]. At the same time, the incubation with wheat germ agglutinin (WGA) and concanavalin A (ConA) made it possible to detect clearly in extracellular matrix $\mathrm{N}$-acetylglucosamine and mannose residues, respectively. Interestingly, an elevated glucose level in the medium did not affect the binding of both lectins, whereas the addition of insulin significantly decreased (to $71 \%$ of control) the binding of concanavalin $A$ to subendothelial matrix.

As the continuation of this work there was the study of influence of non-enzymatically glycosylated albumin, wheat germ agglutinin, and concanavalin A on the deposition of vWF in subendothelial matrix produced in vitro [38]. The scheme of the experiment in this study was based on the concept that subendothelial 
deposition of vWF on collagen can depend on the factors that change the properties of matrix components and the activity of the corresponding proteases. As it was mentioned above, according to our data, insulin, but not high glucose, changes the number of concanavalin A binding sites in subendothelial matrix. The presence of glycosylated albumin in the medium for 1 week did not affect the content of $\mathrm{vWF}$ in the produced subendothelial matrix. On the contrary, both lectins changed, though in different ways, the deposition of vWF. In the case of WGA, an observed decrease in the vWF content correlates with the overall deterioration of the HUVEC viability. Stimulating effect of ConA on the deposition of VWF is of particular interest, taking into account that the high mannose groups play an important role in angiogenesis, and that expression of hepatic mannan-binding lectin is increased at diabetes [39]. Noteworthy, in both mentioned studies on the vWF deposition in subendothelial matrix, HUVECs were cultured in the absence of additional growth factors that can bind to matrix components and play a role in the activation of endothelial cells. Under these conditions, neither high glucose nor glycosylated serum albumin had a pronounced effect on the deposition of vWF in the subendothelial matrix.

\section{Effects on high glucose, insulin and local microenvironment on the apop- tosis of vessel wall cells}

To make a correct comparison of the effects of the factors under study, it was necessary to estimate the viability of endothelial cells in the presence of "diabetic milieu" as well as under an influence of the local endothelium environ- ment [7]. Determination of the number of apoptotic cells showed that at normal glucose concentration in the medium (5.5 mM), the apoptosis index for cultured HUVECs was 3-6\%. Incubation for 6 days under the conditions of significantly elevated glucose level $(28 \mathrm{mM})$, or addition of insulin $(8 \mathrm{mkg} / \mathrm{ml})$, did not affect the number of apoptotic cells. There were no significant changes in the morphology of endothelial cell monolayer. Also, the addition of the medium conditioned by fibroblasts did not change the number of apoptotic cells. Thus, under these conditions, the studied factors of the extracellular environment do not affect the viability of cultured endothelial cells.

In this connection, the most interesting and convincing was the effect of the matrix, produced by endothelial cells under conditions of elevated glucose content, on the viability and apoptosis of pericytes $[40,41]$. The intensity of DNA fragmentation (as the index of apoptosis in pericytes) increased more than 10-times for human pericytes cultured on the matrix produced by HUVECs at high glucose - in comparison to the pericytes seeded onto the matrix produced at normal glucose [41]. It could be mentioned, that pericyte adhesion to high glucose-conditioned matrix decreased, but this effect was much less pronounced (about $19 \%$ to control matrix, produced at normal level of glucose). Moreover, this effect on the level of apoptosis did not depend on the conditions, under which the pericytes were incubated - with increased or normal glucose. Only the conditions of matrix production were of principal importance. As the authors point out, the observed effect can be associated with glycation of matrix components, produced at elevated glucose level in the medium. It fol- 
lows that the interaction of the endothelium and adjacent cells could also be characterized by the inverse vector - from the endothelium to the pericytes (and, probably, the smooth muscle cells).

\section{Conclusion}

The development of diabetic angiopathy is still an issue under study for clinicians as well as for researchers exploring underlying mechanisms of this disease. Now it becomes clear that diabetes is the pathology of multifactorial nature and the effects of "diabetic milieu" factors have to be considered in conjunction with the processes, which determine the viability of target cell population at the tissue level. For vascular endothelium such processes are connected not only with functional integrity of vessel wall cells, but are associated with production and proper organization of extracellular matrix, namely, basal membrane. The understanding of deteriorated properties of subendothelial matrix is critical for elucidation of the cause of developing diabetic angiopathy. In this relation, the appropriate models of the basal membrane formation and vascular remodeling in vitro, which provide the tools to study vascular damage at diabetes at the cellular level, are useful and promising. Such models could be combined with in vivo approaches and applied in future for evaluation of the effects of new therapeutic agents strived toward alleviating of macro- and microvessel pathology at diabetes.

\section{REFERENCES}

1. Brownlee M. The pathobiology of diabetic complications: a unifying mechanism. Diabetes. 2005; 54(6):1615-25.
2. Flyvbjerg A. Diabetic angiopathy, the complement system and the tumor necrosis factor superfamily. Nat Rev Endocrinol. 2010;6(2):94-101.

3. Chawla A, Chawla R, Jaggi S. Microvasular and macrovascular complications in diabetes mellitus: Distinct or continuum? Indian $J$ Endocr Metab. 2016;20(4):546-53.

4. Simon K, Wittmann I. Can blood glucose value really be referred to as a metabolic parameter? Rev Endocr Metab Disord. 2019;20(2):151-160.

5. Kumar V, Cotran R, Robbins S. Basic pathology, $6^{\text {th }}$ edition. - Philadelphia: "W.B.Saunders Company", 1997: $775 \mathrm{p}$.

6. Kefalides $N$, Borel $J$ (eds). Basement membranes: cell and molecular biology. - "Academic Press". 2005; $428 \mathrm{p}$.

7. Nizheradze K, Khoruzhenko A, Tronko N. Study in vitro of the effect of hyperglycemia and cell microenvironment on the von Willebrand factor content in subendothelial matrix. Dopov. Nac. akad. nauk Ukr. 2005;(1): 175-183.

8. Sprague RS, Ellsworth ML. Vascular disease in prediabetes: new insights derived from systems biology. Mo Med. 2010;107(4):265-9.

9. Zhong Y, Yu S, Yu H, Yao J, Men L, Li Y, Wang $Q$, $D u J$. Selenoprotein $\mathrm{S}$ attenuates endothelial dysfunction in a diabetic vascular chip.Exp Gerontol. 2020; 137:110963, 1-12.

10.Tsilibary E. Microvascular basement membranes in diabetes mellitus. J Pathol .2003; 200(4): 537-546.

11. Roy S, Ha J, Trudeau K, Beglova E. Vascular basement membrane thickening in diabetic retinopathy. Curr Eye Res. 2010;35(12):1045-56.

12. Lieleg O, Baumgärtel RM, Bausch AR. Selective filtering of particles by the extracellular matrix: an electrostatic bandpass.Biophys J. 2009;97(6):1569-77.

13.Tarallo S, Beltramo E, Berrone E, Dentelli P, Porta $M$. Effects of high glucose and thiamine on the balance between matrix metalloproteinases and their tissue inhibitors in vascular cells. Acta Diabetol. 2010;47(2):105-11.

14. Fernig DG, Gallagher JT. Fibroblast growth factors and their receptors: an information network controlling tissue growth, morphogenesis and repair. Prog Growth Factor Res. 1994;5(4):353-77. 
15. Tzatsos A, Kandror $K V$. Nutrients suppress phosphatidylinositol 3-kinase/Akt signaling via raptor-dependent mTOR-mediated insulin receptor substrate1 phosphorylation. Mol Cell Biol. 2006;26(1):63-76.

16. Nizheradze K, Tronko N. Use of culture of endothelial cells in studies of vascular pathology in diabetes mellitus. Journal of the NAMSU. 2003;9(4): 713-35.

17. Jaffe EA, Nachman RL, Becker CG, Minick CR. Culture of human endothelial cells derived from umbilical veins. Identification by morphologic and immunologic criteria. J Clin Invest. 1973;52(11): 2745-56.

18. Nachman RL, Jaffe EA. Endothelial cell culture: beginnings of modern vascular biology. J Clin Invest. 2004;114(8):1037-40.

19. Folkman J, Haudenschild CC, Zetter BR. Long-term culture of capillary endothelial cells. Proc Natl Acad Sci U S A. 1979;76(10):5217-21.

20. Richard L, Velasco P, Detmar M. A simple immunomagnetic protocol for the selective isolation and long-term culture of human dermal microvascular endothelial cells. Exp Cell Res. 1998;240(1):1-6.

21. Nightingale T, Cutler D. The secretion of von Willebrand factor from endothelial cells; an increasingly complicated story. J Thromb Haemost. 2013;11(Sup pl 1):192-201.

22. Wagner DD, Urban-Pickering M, Marder VJ. Von Willebrand protein binds to extracellular matrices independently of collagen. Proc Natl Acad Sci U S A. 1984;81(2):471-5.

23. Carr ME. Diabetes mellitus: a hypercoagulable state. $J$ Diabetes Complications. 2001;15(1):44-54.

24. Kessler L, Wiesel ML, Attali P, Mossard JM, Cazenave JP, Pinget $M$. Von Willebrand factor in diabetic angiopathy.Diabetes Metab. 1998;24(4):327-36.

25. Kessler L, Azimzadeh A, Wiesel ML, Coumaros G, Chakfé N, Soyer C, Koehl C, Cazenave JP, Wolf P, Pinget $M$. Effect of insulin on von Willebrand factor release in normal and diabetic subjects: in vivo and in vitro studies. Horm Metab Res. 2001;33(11):674-80.

26. Ascher E, Gade PV, Hingorani A, Puthukkeril S, Kallakuri S, Scheinman M, Jacob T. Thiamine reverses hyperglycemia-induced dysfunction in cultured endothelial cells.Surgery. 2001;130(5):851-8.
27. Li M, Qian M, Kyler K, Xu J. Endothelial-vascular smooth muscle cells interactions in atherosclerosis. Front Cardiovasc Med. 2018;5:151,1-8.

28. de Groot PG, Reinders JH, Sixma JJ. Perturbation of human endothelial cells by thrombin or PMA changes the reactivity of their extracellular matrix towards platelets. J Cell Biol. 1987;104(3):697-704.

29. Li J, Perrella MA, Tsai JC, Yet SF, Hsieh CM, Yoshizumi M, Patterson C, Endege WO, Zhou F, Lee ME. Induction of vascular endothelial growth factor gene expression by interleukin-1 beta in rat aortic smooth muscle cells. J Biol Chem. 1995;270(1):308-12.

30. Rask-Madsen C, King GL. Vascular complications of diabetes: mechanisms of injury and protective factors. Cell Metab. 2013;17(1):20-33.

31. Martin A, Komada MR, Sane DC. Abnormal angiogenesis in diabetes mellitus. Med Res Rev. 2003; 23(2):117-45.

32. Nangia-Makker P, Baccarini S, Raz A. Carbohydrate-recognition and angiogenesis. Cancer Metastasis Rev. 2000;19(1-2):51-7.

33. Markowska AI, Cao Z, Panjwani N. Glycobiology of ocular angiogenesis. Glycobiology. 2014;24(12): 1275-82.

34. Dogné S, Flamion B, Caron N. Endothelial glycocalyx as a shield against diabetic vascular complications: involvement of hyaluronan and hyaluronidases. Arterioscler Thromb Vasc Biol. 2018;38(7): 1427-39.

35. Nieuwdorp M, van Haeften TW, Gouverneur MC, Mooij HL, van Lieshout MH, Levi M, Meijers JC, Holleman F, Hoekstra JB, Vink H, Kastelein JJ, Stroes ES. Loss of endothelial glycocalyx during acute hyperglycemia coincides with endothelial dysfunction and coagulation activation in vivo. Diabetes. 2006;55(2):480-6.

36. Singh R, Barden A, Mori T, Beilin L. Advanced glycation end-products: a review. Diabetologia. 2001;44(2):129-46.

37.Nizheradze KA. Binding of wheat germ agglutinin to extracellular network produced by cultured human fibroblasts. Folia Histochem Cytobiol. 2000; 38(4):167-73.

38. Nizheradze K. Concanavalin A, but not glycated albumin, increases subendothelial deposition of von 
Willebrand factor in vitro. Endothelium. 2006;13(4): 245-8.

39. Hansen TK, Thiel S, Knudsen ST, Gravholt CH, Christiansen JS, Mogensen CE, Poulsen PL. Elevated levels of mannan-binding lectin in patients with type 1 diabetes. $J$ Clin Endocrinol Metab. 2003;88(10):4857-61.

40. Beltramo E, Buttiglieri S, Pomero F, Allione A, D'Alu F, Ponte E, Porta $M$. A study of capillary pericyte viability on extracellular matrix produced by endothelial cells in high glucose. Diabetologia. 2003;46(3):409-15.

41. Beltramo E, Nizheradze K, Berrone E, Tarallo $S$, Porta $M$. Thiamine and benfotiamine prevent apoptosis induced by high glucose-conditioned extracellular matrix in human retinal pericytes. Diabetes Metab Res Rev. 2009;25(7):647-56.

\section{Субендотеліальний матрикс як місце дії факторів «діабетичного середовища» при розвитку ангіопатій}

\section{К. О. Ніжерадзе, А. I. Хоруженко}

Незважаючи на кілька десятиліть інтенсивних досліджень, формування послідовного уявлення про ефекторні механізми, що викликають розвиток діабетичних ангіопатій, залишається нагальним завданням. На рівні всього організму, основними причинами діабетичних мікро- та макроангіопатій вважаються постійна або періодична гіперглікемія, а також зміни рівня інсуліну, глікозильованих білків і ліпопротеїнів, що супроводжується модуляцією внутрішньоклітинних метаболічних шляхів. На тканинному рівні загальним проявом судинної патології при цукровому діабеті $\epsilon$ потовщення васкулярних базальних мембран. У цій роботі, на основі літературних та власних експериментальних даних, як важливий проміжний етап у реалізації впливу факторів «діабетичного середовища» розглянуто зміну локального мікрооточення клітин стінки судин. Особливу увагу приділено вуглеводним детермінантам та депонуванню фактору Віллебранда у субендотеліальному матриксі, продукованому ендотеліальними клітинами в умовах in vitro.

Кл юч о в і с л о в а: діабетичні ангіопатії, гіперглікемія, базальна мембрана, фактор Віллебранда.

\section{Субэндотелиальный матрикс как место действия факторов «диабетической среды» в развитии ангиопатий}

К. А. Нижерадзе, А. И. Хоруженко

Несмотря на несколько десятилетий интенсивных исследований, формирование последовательного представления об эффекторных механизмах, вызывающих развитие диабетических ангиопатий, остается насущной задачей. На уровне целого организма в качестве основных причин диабетических микро- и макроангиопатий рассматриваются стабильная или периодическая гипергликемия, а также изменение уровней инсулина, гликозилированных белков и липопротеинов, что сопровождается модуляцией внутриклеточных метаболических путей. На тканевом уровне, общим проявлением сосудистой патологии при сахарном диабете является утолщение васкулярных базальных мембран. В настоящей работе, основываясь на имеющейся литературе и собственных экспериментальных данных, в качестве важного промежуточного этапа в реализации эффектов факторов «диабетической среды» рассмотрено изменение в локальном микроокружении клеток стенки сосуда. Особое внимание уделено углеводным детерминантам и депонированию фактора Виллебранда в субэндотелиальном матриксе, продуцированном эндотелиальными клетками в условиях in vitro.

Кл юче в ы е с л о в а: диабетические ангиопатии, гипергликемия, базальная мембрана, фактор Виллебранда. 